\title{
Mechanical characterization of mango fruit using compression tests
}

\section{Caracterização mecânica de mangas usando testes de compressão}

\author{
Alan Christie da Silva Dantas, Romulo Barbosa ${ }^{1}$, Acácio Figueiredo Neto1,, \\ Nelson Cárdenas Olivier ${ }^{1}$ and Luiz Iván Negrin Hernández² \\ ${ }^{1}$ Universidade Federal do Vale do São Francisco, Av. Antonio Carlos Magalhães, 310, Santo Antõnio, Juazeiro, Brasil \\ 2 Universidad Central "Marta Abreu" de Las Villas, Carretera Camajuaní Km 5 y 1/2, Santa Clara, Villa Clara, Cuba \\ (*Email: acacio.figueiredo@univasf.edu.br) \\ http://dx.doi.org/10.19084/RCA16095 \\ Received/recebido: 2016.07.19 \\ Received in revised form/recebido em versão revista: 2016.12.20 \\ Accepted/aceite: 2016.12.22
}

\begin{abstract}
A B S T R A C T
Brazil is one of the largest producers of mangoes, and the São Francisco Valley accounts for about 87\% of Brazilian exports of this product to the European market. This study aimed to characterize the mechanical behavior of the fruits according to the maturation stages, in order to prevent physical damage caused by improper handling of the fruit during harvest, storage, processing and transportation. The compression tests were performed on the mango cultivars (Mangifera indica L.) Keitt and Tommy Atkins at different maturation stages in order to characterize the internal elastic modulus and determine the maximum stress until rupture of the sleeve. The fruits showed a decrease in mechanical properties correlated with the increase of maturation stage, for both cutivars. The Tommy Atkins variety showed better mechanical properties probably related to a higher concentration of fibers in the pulp which yields better mechanical stabilization.
\end{abstract}

Keywords: elasticity modulus, mango, maturation, mechanical behavior.

\section{R E S U M O}

O Brasil é um dos maiores produtores de manga e o Vale do São Francisco corresponde por cerca de 87\% das exportações brasileiras deste produto para o mercado europeu. O objetivo deste estudo foi caracterizar o comportamento mecânico dos frutos de acordo com os estádios de maturação, a fim de evitar danos físicos causados pelo manejo inadequado do fruto durante a colheita, armazenamento, processamento e transporte. Os testes de compressão foram realizados nas cultivares de manga (Mangifera indica L.) Keitt e Tommy Atkins em diferentes estádios de maturação para caracterizar o módulo elástico interno e determinar o estresse máximo até a ruptura da manga. Os frutos mostraram diminuição das propriedades mecânicas correlacionadas com o aumento do estádio de maturação, para ambos os cultivares. A variedade Tommy Atkins mostrou melhores propriedades mecânicas, provavelmente relacionadas a uma maior concentração de fibras na polpa, o que resulta em melhor estabilização mecânica.

Palavras-chave: módulo de elasticidade, manga, maturação, comportamento mecânico.

\section{INTRODUCTION}

The production of mangoes (Mangifera indica L.) is of great socioeconomic importance to Brazil. The Vale do São Francisco alone is responsible for approximately $87 \%$ of the exports of this fruit for the European market, according to data from the Brazilian Institute of Fruit - IBRAF in 2009 (Embrapa, 2013).
The need for development of new techniques to improve the production quality is fundamental to optimize production processes such as storage and transportation that increases the quality of the product. Among the various factors that affect the export and marketing of mango are those related to its degradation. In order to solve this problem, there are some postharvest treatments recommended, using appropriate packaging for storage 
and transportation (Choundhury and Costa, 2004). A better understand of the mechanical behavior of the fruit is essential to create a framework of information able to improve the post-harvest procedures and therefore the quality of the agricultural product.

The vast majority of fruit injuries are caused during harvesting, storage and transportation. These damages caused by improper handling and the lack of proper controls results in an acceleration of the ripening and water loss in the fruits, besides promoting the action of microorganisms that cause rot. Damage by impact, vibration or compression cause imperfections in the skin that diminish the commercial value of the fruit (Cocozza, 2003).

In this scenario, the mechanical tests are an important alternative for the determination of mechanical properties of agricultural products which may be used for both grain (Kang et al., 1995; Henry-Zachary et al., 2000; Couto et al., 2002) and fruits (Linares, 1996; Lucena et al., 2000; Yousefi et al., 2016). These tests are a valuable tool in determining the maximum permissible loads and handling of these materials during the post harvest.

This work studied the mechanical properties of mango fruits of two different cultivars: Tommy Atkins and Keitt. The studies were carried out using compression tests and analyze of the geometric stress distribution in the fruits.

\section{MATERIALS AND METHODS}

The tests were carried out in a compression universal testing machine WAW Class 1" (Time Group Inc), connected to the computer using the software Winwaw V1.0, using a test speed of $5 \mathrm{~mm} / \mathrm{min}$. In order to determine the elasticity of the modulus in the sleeves a maximum deformation of $22.5 \mathrm{~mm}$ and geometric analysis was monitored in the fruit. The fruits were positioned between parallel plates and the tests were carried out until failure of the fruit sleeve. The results were submitted to analysis of variance, using Tukey test at $5 \%$ probability, by means of the Assistat software, Version 7.7 beta (Silva, 2014).

Tests were performed in fruits of the cultivars Tommy Atkins and Keitt on the stage 1, 2 and 3 of maturation. The maturation phase was determined by evaluation of the color of the fruit pulp after the mechanical tests (Brecht etal., 2003). A minimum of 15 samples was evaluated for each maturation phase and cultivar. For the tests the fruits were positioned at the natural rest state, as shown in Figure 1. In this position, the fruit presents increased stability, and this position is normally used for packaging, storage and, consequently, transportation of the fruits.

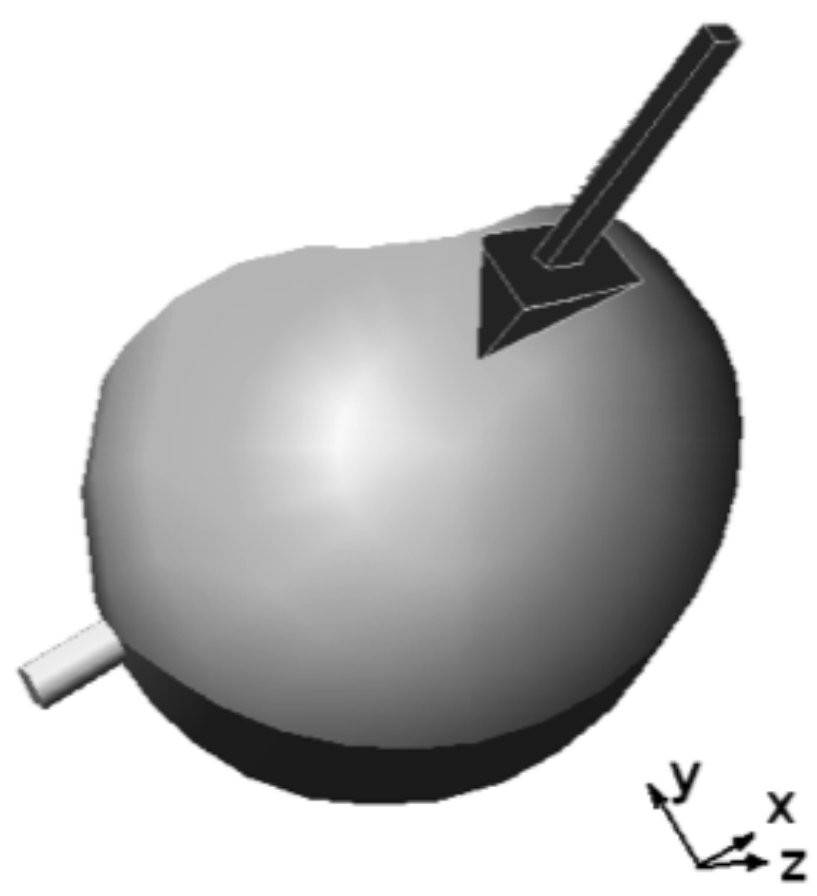

Figura 1 - Schematic representation of the mango fruit in the rest position, used on the tests. The black arrow indicates the direction of load application.

The Mango fruit has a shape that can be approximated to an ellipsoid body. When subjected to a compressive load, the contact area between the fruit and the plates is initially minimal. However, due to the deformation of the physical structure of the sleeve, the contact area increases during application of compressive load and reach a maximum value just before rupture of the skin. Thus, to calculate the strain in the fruits depending on the force applied in the compression test, we used the final contact area that represents the maximum deformation, prior to rupture. For this, the fruit was considered to be a spherical shape, as shown in Figure 2. 
Thus, the maximum Ac contact area between the plates and fruit, can be calculated according to equation 1 .

$$
A_{c}=2 \pi \cdot r_{\text {esf }} \cdot h
$$

Where $r_{\text {esf }}$ is the radius of the sphere, and $\mathrm{h}$ is the height of the dome, both in meters.

According to the Hertz contact theory, for determining the maximum surface pressure and elastic modulus of a body, pressed between two flat plates, as proposed by Timoshenko \& Goodier (1951) and applied to the second spherical fruit Linares (1996), the modulus of elasticity (E) of the fruit can be found using equation 2 .

$E=0,75 F\left(1-\mu^{2}\right) \cdot \frac{1}{D^{3 / 2}} \cdot \frac{1}{R^{1 / 2}}$

Where $\mathrm{F}$ is the force in Newton, $\mu$ is the Poisson's ratio, $\mathrm{R}$ is the radius of the sphere in meters and $\mathrm{D}$ is the deformation in meters.

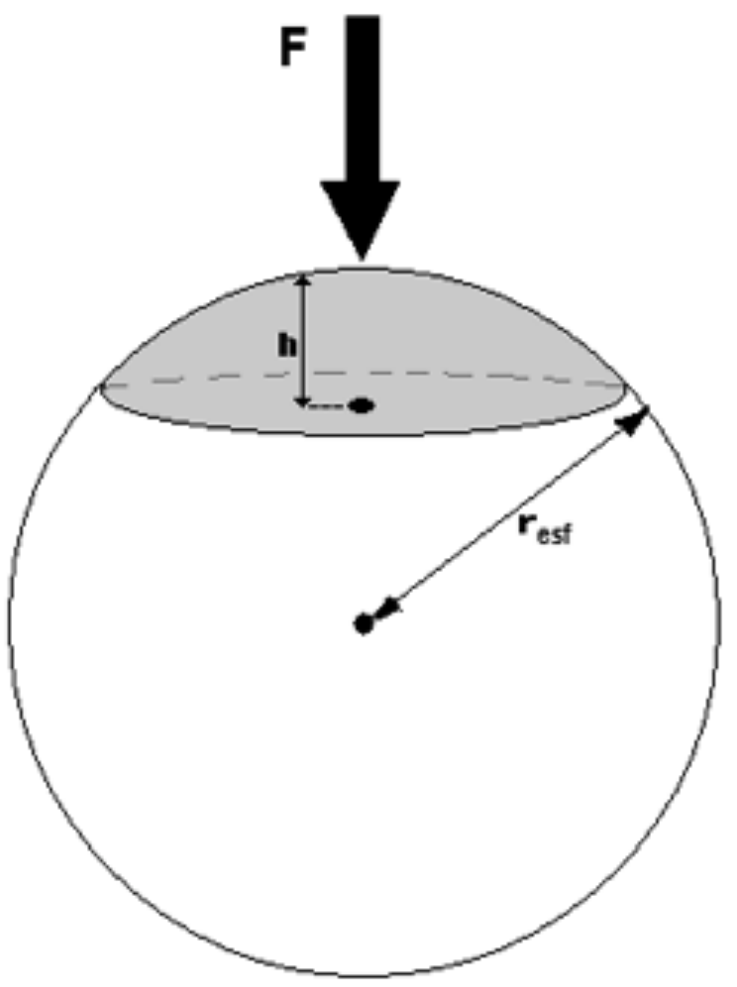

Figura 2 - Cap area of a spherical body, used to obtain the value of the maximum contact area before rupture.
To assess the effect of the spherical shape on the results, an equation for ellipsoidal bodies proposed by Laurenti (1997) was used. This method approximates the elliptical geometry to a sphere with an equivalent radii according to Figure 3.

Thus the dimension " $r$ " and " $R$ " may be used to calculate the modulus of elasticity, E, of an ellipsoid compressed between flat plates, according to equation 3.

$E=\frac{0,530 F\left(1-\mu^{2}\right)}{D^{3 / 2}}\left(\frac{1}{r} \cdot \frac{1^{1 / 2}}{R}\right)$

Where $\mathrm{F}$ is the force in Newton, $\mu$ is the Poisson ratio, $\mathrm{r}$ and $\mathrm{R}$ are the radii of curvature of the convex contact points in meters and $\mathrm{D}$ is the deformation in meters.

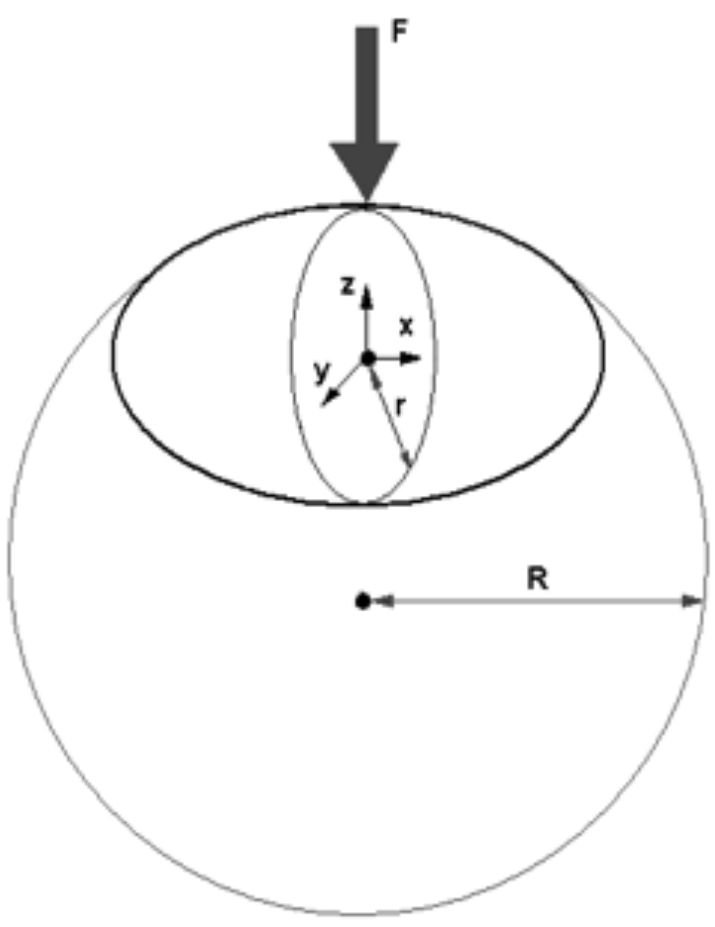

Figura 3 - Radii of curvature of the convex sleeve used to determine the modulus of elasticity according Laurenti (1997). 


\section{RESULTS AND DISCUSSION}

After compression tests on the fruits, it could be verified that the mechanical strength decreases with the maturation stage of the fruit. The variety Tommy Atkins showed behavior similar to the fruits of Keitt for all stages of maturation. Figure 4 shows the force $\mathrm{x}$ deformation curves for fruits of Keitt and Tommy Atkins varieties at different stages of maturation. A decrease can be seen in the slope of the curve with the increase of maturation, regardless of the variety studied that shows a decrease of firmness due to physical chemical changes in the pulp of the fruits.

According to Kays (1991), changes in firmness may affect the duration of storage and shelf-life extension of fruit, being predominantly caused by disruption of the cell wall, caused by complex interactions of the activities of the amylase, pectin and galactosidases enzymes (Tucker, 1993). The decrease in fruit firmness of Tommy Atkins mango cultivar was studied by Lucena et al. (2000), realizing that the physicochemical characterization of the fruits at different stages of maturation. They reported a decrease of the the firmness with advance of maturity.

The cultivar Keitt presented lower firmness than the Tommy Atkins variety of samples, characterized by a lower slope of the force vs. deformation.

From the tests were determined the maximum forces supported until break the skin of the fruit.

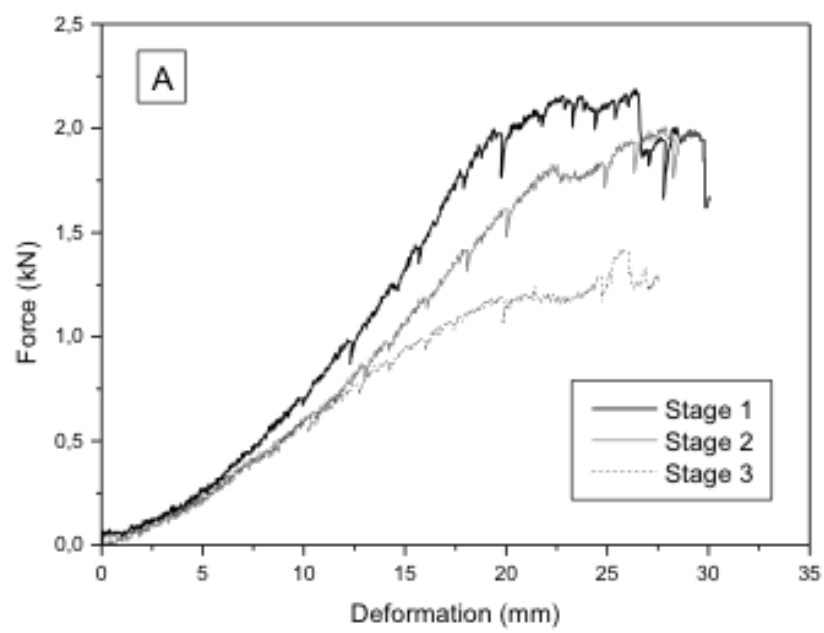

This disruption was observed visually in the transverse axis in almost all fruits. Table 1 shows the maximum stresses applied during experiments for the varieties Keitt and Tommy Atkins. The cultivar Tommy Atkins presented higher values of stress in comparison to those showed for the cultivar Keitt, probably due to a higher fiber content presented in the pulp of Tommy Aktins variety. The presence of fibers promotes a better distribution of the mechanical load across the matrix and consequently improves the mechanical strength of the body. The chemical structure of mango insoluble fibers is mainly formed by cellulose but can contains lignin, hemicellulose, pectins, gums and mucilages. Insoluble dietary fiber (IDF) are considered to be insoluble, non-viscous, slowly fermentable (Roberfroid, 1993; Ramulu et al., 2003). This kind of fiber is poorly affected by the ripening process and tends to remain constant during ripening process Andrade Jr. and Andrade (2015), so that fruits with high amount of fibers tend to presents lower decrease of the mechanical properties by increase of the ripening stage.

Table 1 - Maximum strength at the rupture threshold for the cutivars Keitt and Tommy Atkins in the stages 1, 2 and 3 of maturation. For each line, values with different letters differ significantly $(P<0.05)$

\begin{tabular}{cccc}
\hline Cultivar & \multicolumn{3}{c}{ Maximum strength (kN) } \\
& Stage 1 & Stage 2 & Stage 3 \\
\hline Keitt & $1.72 \pm 0.17 \mathrm{a}$ & $1.59 \pm 0.18 \mathrm{a}$ & $1.20 \pm 0.20 \mathrm{~b}$ \\
Tommy Atkins & $2.02 \pm 0.16 \mathrm{a}$ & $1.84 \pm 0.18 \mathrm{~b}$ & $1.61 \pm 0.10 \mathrm{~b}$ \\
\hline
\end{tabular}

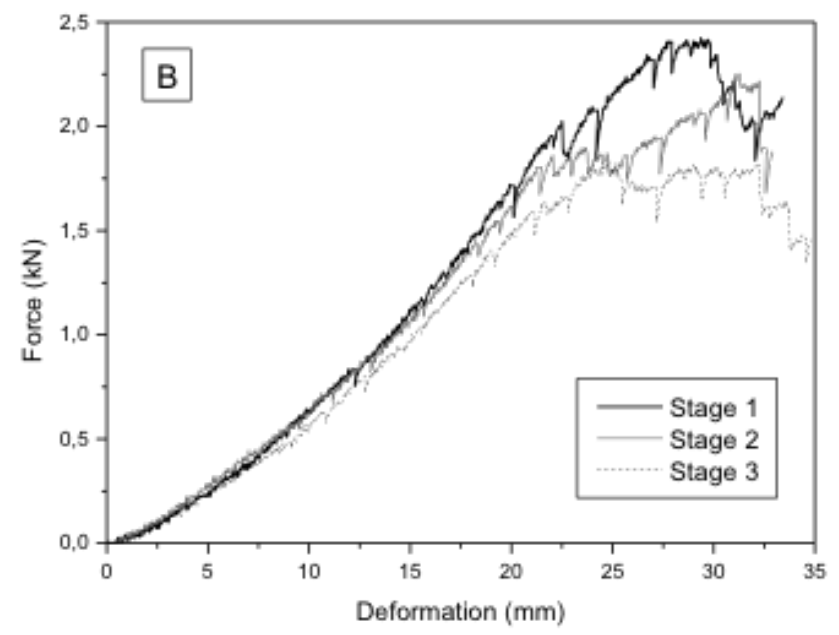

Figura 4 - Force deformation curve for Keitt (A) and Tommy Atkins (B) mangoes at different stages of maturation. 
Table 2 - Modulus of elasticity of the Keitt and Tommy Atkins varieties obtained by compression test with the application of equations 2 and 3

\begin{tabular}{cccc}
\hline Variety & $\begin{array}{c}\text { Maturation } \\
\text { Stage }\end{array}$ & $\begin{array}{c}\text { E (MPa) } \\
\text { Spherical } \\
\text { model } \\
\text { (Eq. 2) }\end{array}$ & $\begin{array}{c}\text { E (MPa) } \\
\text { Ellipsoid } \\
\text { model } \\
\text { (Eq. 3) }\end{array}$ \\
\hline \multirow{3}{*}{ Keitt } & 1 & $2.11 \pm 0.17$ & $1.84 \pm 0.14$ \\
& 2 & $1.90 \pm 0.15$ & $1.64 \pm 0.12$ \\
Tommy & 3 & $1.52 \pm 0.12$ & $1.34 \pm 0.10$ \\
Atkins & 1 & $1.99 \pm 0.15$ & $1.75 \pm 0.13$ \\
& 2 & $1.88 \pm 0.12$ & $1.71 \pm 0.13$ \\
\hline
\end{tabular}

The modulus values obtained using equation 2 for spherical bodies, and equation 3 for ellipsoidal bodies can be seen in Table 2. It is possible to observe a reduction in modulus of elasticity with increasing stage of maturity, regardless of the variety of the fruit. However, this effect was more pronounced in the Keitt cultivar, which also contained smaller amounts of fiber, as opposed to the Tommy Atkins. The fruits of the variety Tommy Atkins have a firm flesh with average fiber content of approximately $1.21 \mathrm{~g} / 100 \mathrm{~g}$ while in the Keitt variety, fibers are only present around the seed (Manica, 2001). It can be seen also, that both equations lead to similar values. However, the ellipsoidal model leads to smaller values of maximal resistance and for this reason is the most recommendable to determine the maximal strength of the fruits in or due to achieve more secure loads.

\section{CONCLUSIONS}

The maximum force supported by the Tommy Atkins variety is higher than that of the Keitt mangoes, however the considerable deviation in the results are due to the agricultural nature of the materials.

The resistance of the Tommy Atkins variety is less susceptible to the effect, caused by an increased stage of maturity, than the Keitt variety due to the greater presence of fibers that mechanically stabilizes the fruit.

Maturation promotes changes in the cell walls of the fruit which cause a reduction of the durability of its mechanical properties.

The ellipsoidal model is a good simplification to evaluate the mechanical behavior of mangoes, due to the similar geometry and because this model leads to smaller values of maximal strength that result on more secure admissible loads.

\section{ACKNOWLEDGEMENTS}

To "Fundação de Amparo a Pesquisa do Estado da Bahia" (FAPESB) for their financial assistance through the mango project.

\section{REFERENCES}

Andrade Jr., M.C. de \& Andrade, J.S. (2015) - Changes in pectinases, dietary fibers, and physicochemical indices related to the flavor of cubiu fruits during ripening, Acta Scientiarum. Agronomy, vol. 37, n. 2, p. 171-179. http://dx.doi.org/10.4025/actasciagron.v37i2.19683

Brecht, J.K., Chau, K.V., Fonseca, S.C., Oliveira, F.A.R., Silva, F.M., Nunes, M.C.N. \& Bender, R.J. (2003) Maintaining optimal atmosphere conditions for fruits and vegetables throughout the postharvest handling chain. Postharvest Biology and Technology, vol. 27, n. 1, p. 87-101. http://dx.doi.org/10.1016/S0925-5214(02)00185-0

Choudhury, M.M. \& Costa, T.S. (2004) - Perdas na cadeia de comercialização da manga. Embrapa Semi-Árido, Petrolina, PE. 44 p.

Cocozza, F.D.M. (2003) - Maturação e conservação de manga 'Tommy Atkins' submetida à aplicação pós-colheita de 1-metilciclopropeno. Tese (Doutorado) - Programa de Pós-Graduação em Engenharia Agrícola, Universidade Estadual de Campinas, Faculdade de Engenharia Agrícola. UNICAMP, Campinas, SP. 226 p.

Couto, S.M.; Batista, C. da S.; Peixoto, A.B. \& Devilla, I.A. (2002) - Comportamento mecânico de frutos de café: módulo de deformidade. Revista Brasileira de Engenharia Agrícola e Ambiental, vol. 6, n. 2, p. 285-294. http://dx.doi.org/10.1590/S1415-43662002000200018 
EMBRAPA (2013) - Cultivo da Manga. [cit. 2013.06.06]. http://sistemasdeproducao.cnptia.embrapa.br/FontesHTML/ Manga/CultivodaMangueira 2ed/mercado.htm

Henry-Zachary, A.; Su, B. \& Zhang, H. (2000) - Resistance of soya beans to compression. Journal of Agricultural Engineering Research, vol. 76, n. 2, p. 175-181. http://dx.doi.org/10.1006/jaer.2000.0546

Kang, Y.S.; Spillman, C.K.; Steele, J.L. \& Chung, D.S. (1995) - Mechanical properties of wheat. Transactions of the ASAE, vol. 38, n. 2, p. 573-578.

Kays, S.J. (1991) - Metabolic processes in harvested products. In: Postharvest Physiology of Perishable Plant Products. Van Nostrand Reinhold, New York, p. 75-142.

Laurenti, R. (1997) - Estudo metodológico das geometrias de corpos vegetais para ensaios mecânicos. UNICAMP, Universidade Estadual de Campinas, Faculdade de Engenharia Agrícola, 245 p. Dissertação (Mestrado). Campinas, SP.

Linares, A.W. (1996) - Estudo do comportamento viscoelástico de frutos esféricos. Universidade Estadual de Campinas, Faculdade de Engenharia Agrícola, 147 p. Dissertação (Mestrado). UNICAMP, Campinas, SP.

Lucena, E.M.P.; Silva Júrnior, A. \& Campelo, I.K.M. (2000) - Caracterização físico-química da manga (Mangifera indica L.), variedade Tommy Atkins, em diferentes estágios de maturação. In: Congresso Brasileiro de Ciência de Tecnologia de Alimentos, 17, Fortaleza. Resumos. Sociedade Brasileira de Ciência e Tecnologia de Alimentos, Fortaleza. vol. 2, p. 5246.

Manica, I.; Icuma, I.M.; Malavolta, E.; Ramos, V.H.V.; Oliveira Jr., M.E. de; Cunha, M.M. da \& Junqueira, N.T.V. (2001) - Manga: tecnologia, produção, agroindústria e exportação. Cinco Continentes, Porto Alegre. 617 p.

Ramulu, P. \& Rao, P.U. (2003) - Total, insoluble and soluble dietary fiber contents of Indian fruits. Journal of Food Composition and Analysis, vol. 16, n. 6, p. 677-685.

Roberfroid, M. (1993) - Dietary fibre, inulin and oligofructose: a review comparing their physiological effects. CRC Critical Reviews in Food Science and Nutrition, vol. 33, n. 2, p. 103-148. http://dx.doi. org/10.1080/10408399309527616

Silva, F.A.S. (2014) - ASSISTAT Soft: Assistência Estatística. Versão 7.7 beta.

Timoshenko, S. \& Goodier, J. N. (1951) - Theory of Elasticity. McGraw-Hill Book Company, Inc. Second Edition, $506 \mathrm{p}$.

Tucker, G.A. (1993) - Introduction. In: Seymour, G.B.; Taylor, S.E. and Tucker, G.A. (Eds.) - Biochemistry of fruit ripening. Chapman \& Hall, London. Chap. 1, p. 255-266.

Yousefi, S.; Farsi, H. \& Kheiralipour, K. (2016) - Drop test of pear fruit: Experimental measurement and finite elements modelling. Biosystems Engineering, vol. 147, p. 17-25. http://dx.doi.org/10.1016/j.biosystemseng.2016.03.004 